\title{
Correction to: How Do Local Folks Value Wild Meat, and Why It Matters? A Study in the Democratic Republic of Congo
}

\author{
Nathalie van Vliet $^{1}$. Jonas Kambale Nyumu ${ }^{1,2}$. Sagasse Nziavake ${ }^{1}$. Jonas Muhindo ${ }^{1}$. Evi A.D. Paemelaere ${ }^{1}$ (i) \\ Robert Nasi ${ }^{1}$
}

Published online: 3 December 2021

๑) Springer Science+Business Media, LLC, part of Springer Nature 2021

Correction to: Human Ecology (2021)

https://doi.org/10.1007/s10745-021-00275-4

Article title in the original publication contains a mistake.

The original article has been corrected.

Publisher's Note Springer Nature remains neutral with regard to jurisdictional claims in published maps and institutional affiliations.

The original article can be found online at https://doi.org/10.1007/ s10745-021-00275-4.

Nathalie van Vliet

nathalievanvliet@yahoo.com

Evi A.D. Paemelaere

pwsolutions.main@gmail.com

1 Centre for International Forestry Research (CIFOR), Bogor, Indonesia

2 Université de Kisangani, Kisangani, Congo 